\title{
Poder Judiciário e Administração Pública: interferência indevida na capacidade de tomada de decisão e execução de políticas públicas de combate a COVID-19
}

rdai.com.br/index.php/rdai/article/view/423

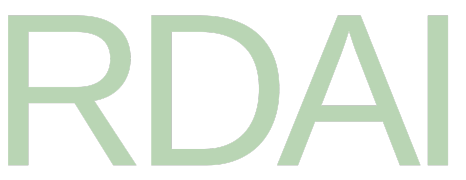

\section{Autores}

Edvaldo Nilo de Almeida Instituto Brasileiro de Mercado de Capitais (Brasília, DF, Brasil)

\section{DOI:}

https://doi.org/10.48143/rdai.19.ena

\section{Palavras-chave:}

Poder Judiciário, COVID-19, Administração Pública, Reserva de administração

\section{Resumo}

Este estudo tem por objeto demonstrar a ilegitimidade jurídica da interferência do Poder Judiciário na capacidade de tomada de decisão e execução de políticas públicas de combate à Covid-19 pela Administração Pública. A metodologia consiste na análise da doutrina jurídica e jurisprudencial relacionadas ao tema, utilizando-se os métodos bibliográfico e documental, com ênfase nas fontes de estudo do Direito Constitucional e Teoria Geral do Direito. Nessa senda, o problema a ser respondido é se o atual processo de aplicação do Direito pelo Poder Judiciário em relação às políticas públicas da Administração Pública de combate à Covid-19 pode ser considerado conflitante com o ordenamento jurídico brasileiro. Conclui-se, assim, que os danos causados pela troca de papéis constitucionais causam a paralisia do Estado e ferem, normativamente, os princípios constitucionais, quais sejam: o princípio republicano, do Estado Democrático de Direito, e da separação de poderes.

\section{Biografia do Autor}

\section{Edvaldo Nilo de Almeida, Instituto Brasileiro de Mercado de Capitais} (Brasília, DF, Brasil) 
Professor do IBMEC (Brasília, DF, Brasil). Doutor em Direito Público pela PUC-SP. Possui pós-graduação no curso de especialização em Direito Tributário pela Fundação Faculdade de Direito da UFBA. Especialista em Direito Tributário pelo IBET. Possui pósdoutorado em Democracia do Ius Gentium Coimbra e associado à Universidade de Coimbra. Desenvolve pós-doutoramento em Direito Tributário da UERJ e estágio de pesquisa de pós-doutorado em Direitos Humanos pela Universidade de Salamanca. Procurador do Distrito Federal. ORCID:

(iD) 0000-0001-843ㅇ-04료 | edvaldonalmeida@yahoo.com.br

\section{Referências}

ALEXY, Robert. Teoria de los derechos fundamentales. Tercera reimpresión. Madrid: Centro de Estudios Políticos y Constitucionales, 2002.

ATALIBA, Geraldo. República e Constituição. 2. ed. 2. tiragem. São Paulo: Malheiros, 2001.

ÀVILA, Humberto Bergmann Teoria dos princípios. São Paulo: Malheiros, 2003.

BARROSO, Luís Roberto. Interpretação e aplicação da constituição. 5. ed. São Paulo: Saraiva, 2003.

BARROSO, Luís Roberto. Constituição, Democracia e Supremacia Judicial: direito e política no Brasil contemporâneo. Revista da Faculdade de Direito da UERJ, [S.1.], n. 21, p. 01-50, jun. 2012. Disponível em: [www.epublicacoes.uerj.br/index.php/rfduerj/article/view/1794]. Acesso em: 23.05.2021.

BASTOS, Celso Ribeiro. Hermenêutica e interpretação constitucional. 3. ed. São Paulo: Celso Bastos Editor, 2002.

BONAVIDES, Paulo. Curso de direito constitucional. 13. ed. São Paulo: Malheiros, 2003. BONAVIDES, Paulo. Teoria do estado. 4. ed. São Paulo: Malheiros, 2003.

BRANCO, Paulo Gustavo Gonet; COELHO, Inocêncio Mártires; MENDES, Gilmar Ferreira. Curso de Direito constitucional. São Paulo: Saraiva, 2007.

BRITTO, Carlos Ayres. Teoria da constituição. Rio de Janeiro: Forense, 2003.

BOBBIO, Norberto. Estado, governo, sociedade: para uma teoria geral da política. 10. ed. Rio de Janeiro: Paz e Terra, 2003.

CANOTILHO, José Joaquim Gomes. Direito constitucional e Teoria da Constituição. 5 . ed. Coimbra: Almedina, 2002.

COELHO, Inocêncio Mártires. Interpretação constitucional. 3. ed. São Paulo: Saraiva, 2007.

DWORKIN, Ronald. Levando os direitos a sério. São Paulo: Martins Fontes, 2002. 
ESPÍNDOLA, Ruy Samuel. Princípios constitucionais e atividade jurídico-administrativa: anotações em torno de questões contemporâneas. In: George Salomão Leite (Org.). Dos princípios constitucionais: considerações em torno das normas principiológicas da Constituição. São Paulo: Malheiros, 2003.

ESPÍNDOLA, Ruy Samuel. Conceito de princípios constitucionais. 2. ed. São Paulo: Ed. RT, 2002.

FERRAZ JR., Tercio Sampaio. Introdução ao estudo do direito: técnica, decisão e dominação. 4. ed. São Paulo: Atlas, 2003.

FERREIRA, Jorge. Regime jurídico dos inquéritos parlamentares. Coimbra: Almedina, 1999.

HABERLE, Peter. Hermenêutica constitucional. Reimpr. Porto Alegre: Safe Editor, 2002. HESSE, Konrad. A força normativa da Constituição. Porto Alegre: Safe Editor, 1991.

KRAMER, Larry. The people themselves: popular constitutionalism and judicial review. New York: Oxford University Press, 2004.

LARENZ, Karl. Metodologia da ciência do direito. 3. ed. Lisboa: Fundação Calouste Gulbenkian, 1997.

MAXIMILIANO, Carlos. Hermenêutica e aplicação do direito. 19. ed. Rio de Janeiro: Forense, 2002.

MIRANDA, Jorge. Manual de direito constitucional. 4. ed. Coimbra: Coimbra, 200o. t. II. MIRANDA, Jorge. Teoria do estado e da constituição. Rio de Janeiro: Forense, 2002. MULLER, Friedrich. Direito-Linguagem-Violência. Porto Alegre: Safe Editor, 1995. PIÇARRA, Nuno. A separação de poderes como doutrina e princípio constitucional: um contributo para o estudo das suas origens e evolução. Coimbra: Coimbra Editora, 1989. ROTHENBURG, Walter Claudius. Princípios constitucionais. Porto Alegre: Safe Editor, 1999.

RUSSOMANO, Rosah. Curso de direito constitucional. 4. ed. Rio de Janeiro: Freitas Bastos, 1984.

SILVA, José Afonso da. Sistema Constitucional da Seguridade Social. Direito tributário: estudos avançados em homenagem a Edvaldo Brito. São Paulo: Atlas, 2014.

STRECK, Lenio Luis Hermenêutica jurídica e(m) crise. 4. ed. Porto Alegre: Livraria do Advogado, 2003. 
SUNSTEIN, Cass R. The New Legal Realism. University of Chicago Law Review, Forthcoming, U of Chicago Law \& Economics, Olin Working Paper n. 372, U of Chicago, Public Law Working Paper n. 191. Disponível em: [https://ssrn.com/abstract=1070283]. Acesso em: 23.05.2021.

TEMER, Michel. Elementos de direito constitucional. 19. ed. São Paulo: Malheiros, 2003.

VIEIRA, José Ribas et al. O Supremo Tribunal Federal como arquiteto institucional: a judicialização da política e o ativismo judicial. Versus: Revista de Ciências Sociais Aplicadas do CCJE, Rio de Janeiro, v. 02, p. 74-85, 2009.

\section{Publicado}

2021-12-15

\section{Como Citar}

ALMEIDA, E. N. de. Poder Judiciário e Administração Pública: interferência indevida na capacidade de tomada de decisão e execução de políticas públicas de combate a COVID19: Judiciary and Public Administration: undue interference in the decision-making capacity and execution of public policies to combat COVID-19. Revista de Direito

Administrativo e Infraestrutura | RDAI, São Paulo: Thomson Reuters - Livraria RT, v. 5, n. 19, p. 191-212, 2021. DOI: 10.48143/rdai.19.ena. Disponível em:

https://rdai.com.br/index.php/rdai/article/view/423. Acesso em: 7 fev. 2022.

\section{Edição}

V.5‥19_(2021)

\section{Seção}

Direito Administrativo: Controle

\section{Licença}

\section{(1) 9}

BY NC ND

Este trabalho está licenciado sob uma licença Creative Commons Attribution-

NonCommercial-NoDerivatives 4.0 International License.

(CC BY-NC-ND).

Este é um resumo (e não um substituto) da licença

Regras para publicação

Direitrizes Editoriais

Direitos e Deveres 
Errata e Retratação

Preservação e Plagiarismo

Revisão e Avaliação 
